\title{
INFLUENCE OF HYPERBARIC OXYGENATION AND ITS USE IN URINARY TRACT DISEASES
}

\author{
Małgorzata Skiba, Agnieszka Pedrycz
}

Department of Histology and Embryology, Medical University in Lublin, Poland

\section{ABSTRACT}

In this publication, we adduce examples of the use of hyperbaric oxygen therapy in urinary tract diseases. Hyperbaric oxygen therapy has been proved to have a positive influence on the kidneys of animals with diabetes, sepsis or undergoing chemotherapy. In the literature, we can also find many examples of the use of hyperbaric therapy with good clinical outcomes in human patients with prostatic hypertrophy, pyelonephritis, and hemorrhagic cystitis. The first trials of this kind of treatment of urinary tract diseases were started at the end of the twentieth century. In spite of the promising results, and numerous reports on the effectiveness of this non-invasive method of treatment, it is not currently used on a regular basis.

Because many factors such as time, multiple applications, the parameters used in the hyperbaric chamber as well as the medications taken by the patient affect the quality of the result, further studies are needed to make hyperbaric therapy more suitable and safer for each patient.

Key words: hyperbary, hyperbaric oxygenation, urinary tract disease.

ARTICLE INFO

PolHypRes 2016 Vol. 56 Issue 3 pp. 25 - 32

ISSN: 1734-7009 elSSN: 2084-0535

DOI: $10.1515 /$ phr-2016-0016

Pages: 8 , figures: 0 , tables: 0

page www of the periodical: www.phr.net.pl

Publisher

Polish Hyperbaric Medicine and Technology Society

\section{Review article}

Delivery date: 04.07.2016r

Date of approval for print: $15.08 .2016 r$. 


\section{INTRODUCTION}

Hyperbaric is the term used to describe the exertion of a pressure higher than atmospheric pressure; "Hyper" coming from the Greek word for excess, the second part of the word being derived from the meteorological term "baric" suggestive of the relation to atmospheric pressure. The human is exposed to hyperbaric conditions when he dives or when he is placed inside specially constructed hyperbaric chambers. The chambers are used for therapeutic or experimental purposes. Patients who are placed inside the chamber are subjected to the sum of the atmospheric pressure and the pressure prevailing inside the chamber.

Despite the proven benefits of elevated pressure on the therapeutic treatment of humans, it is controversial because it may cause many complications. The history of the use of hyperbaric therapy dates back to the seventeenth century, when the positive impact of weather change on pulmonary disorders was observed, and when the first trials of modulating the ambient pressure in a patient's surrounding began. The creator of the first hyperbaric chamber was the British priest- Henshaw. Unfortunately, the side effects that occurred during therapy caused the suppression and long-term stagnation in the development and use of hyperbaric treatment. The main problem was to create the optimum pressure for participants; excessive pressure caused decompression sickness, while too little lead to hypoxia.

A positive turn in the use of hyperbaric therapy occurred in the nineteenth century. In 1855, Bertin created the first textbook of hyperbaric medicine. At the same time, many hyperbaric chambers were being created in European countries. The first hyperbaric chambers used compressed air due to reports of the toxicity of oxygen. In the early twentieth century Cunningham, who was a professor of anesthesiology from Kansas University, observed that patients with cardiovascular problems who live above sea level feel worse than those who live below the sea level. He came to the conclusion that raising the atmospheric pressure can be beneficial.

However, his real success was creating the chamber to treat the pandemic of Spanish flu as well as to treat patients with diabetes, hypertension and cancer. In 1937 Behnke and Shaw used a hyperbaric chamber to treat decompression sickness by using oxygen for the first time [1].

Twenty-two years later Borema conducted an experiment that changed scientists' point of view. He exposed a pig, whose blood had been cleaned of hemoglobin proteins, to a pressure of 3 ATA, for 45 minutes. During the trial the pig breathed pure oxygen. This experiment proved, that under the conditions of hyperbaric oxygen, sufficient tissue oxygenation may be provided by oxygen physically dissolved in the plasma.It is worth mentioning that solubility of oxygen in plasma increases fourteen times under pressure of 2-3 ATA [2].

Hyperbaric oxygenation leads to more efficient tissue oxygenation, where due to vasospasm, or severe anemia, erythrocytes are not able to reach. It also improves tissue oxygenation when hemoglobin is blocked by carbon monoxide. Not only does the solubility of oxygen in plasma increase under such conditions, but it also increases its concentration gradient between blood and tissues. This increases the strength of the diffusion which leads to a better oxygenation of tissues.
Studies also revealed other positive effects of hyperbaric oxygenation:

- pressure increase leads to a reduction in the quantity of gas bubbles in blood,

- it reduces the time of the half-life of carboxyhemoglobin,

- capillaries in damaged tissues shrink which leads to a reduction of swelling,

- it increases the number of fibroblasts,

- it increases the quantity of capillaries,

- it leads to inhibition of anaerobic bacteria growth -it causes growth of osteoclast activity.

There are many indications for treatments in which hyperbaric therapy has proven to be helpful. For example, treatment of decompression sickness, emboli, carbon monoxide poisoning syndrome, clostridium gas gangrene, soft tissue injuries, slow-healing wounds, intracranial abscesses, late radiation damage, existing conditions, high blood loss, transplant skin with risk of rejection, thermal burns, actinomycosis have all proven to be effective [3].

Indications for hyperbaric oxygen treatment are determined by the Undersea and Hyperbaric oxygenation of the Undersea Medical Society (UNSEA).

In most cases, hyperbaric therapy is considered safe when pure oxygen is given at a pressure below 3 ATA [4]

The first attempts to treat diseases of the urinary tract utilising hyperbaric conditions started at the end of the twentieth century. However, despite numerous reports on the effectiveness of this non-invasive method of treatment, it is still not commonly used in treatment of any of the urinary tract diseases.

Tests on animals have shown that hyperbaric therapy can have a protective effect on the changes caused by ischemia and on the amount of free radicals that appear after blood resupply. It seems that the major problem limiting the use of hyperbaric therapy is still the increased production of harmful oxygen radicals, and the ability to use excess pressure in relation to the host; issues that may lead to the associated side effects.

Scientists have conducted an experiment on guinea pigs which were put in a hyperbaric chamber at a pressure of 6 ATA for 30 minutes. As a result of this test, scientists observed damage to epithelial cells of the proximal tubules [5].

Scientists studied the changes that occur in the renal cortex in septic rats undergoing hyperbaric pressure of 2ATA. There were no histological changes in the kidneys of healthy rats and three rats with a disease placed in the chamber. Other septic animals had significantly less degenerative changes in the tubules and glomeruli than diseased rats that did not undergo treatment. Comparison of these results suggests that the effectiveness of hyperbaric oxygen is impacted by many factors, but it mainly changes depending on the applied pressure parameters and the duration of therapy.

In research conducted by Aydinoz et al, rats that received nephrotoxic cisplatin were put in a chamber under pressure of 2.5 ATM once or twice a day. Rats that had contact with hyperbaric oxygen only once a day produced defensive mechanisms. Their parameters of renal failure improved and histopathological changes were less visible compared to the control group.

In contrast, parameters and histological changes did not differ from a group of animals which had not 
undergone treatment to rats that received treatment twice a day. Scientists came to the conclusion that hyperbaric therapy applied twice a day enhances the nephrotoxic potential of cisplatin but through mechanisms independent of oxygen radicals [6].

Hakan Ay and his colleagues studied the effects of hyperbaric therapy on animal kidneys as well. They divided rats into three groups: the first one in which rats received intraperitoneal cyclosporin, the second one in which animals were placed in the hyperbaric chamber under 2.5 ATA of pressure for 60-120 minutes, and a third one in which the animals were subjected to the influence of both factors at the same time.

The researchers measured the level of oxidative stress in kidney cells using the appropriate markers and checking the parameters of renal failure. Cyclosporin turned out to be nephrotoxic. Animals which received it suffered from an increase of markers of oxidative stress.

Parameters of the study group subjected to elevated pressure did not differ from the parameters of the control group. Rats from the third group which were subjected to high pressure and were given cyclosporine showed a lower level of oxidative stress markers than animals in the first group that got the same dose of cyclosporin. Anyway, renal parameters of third group did not improve. The results of this study indicate that reactive oxygen species are involved in nephrotoxicity induced by cyclosporin which does not directly cause kidney damage.

It should also be noticed that the type of active substance - medications taken before or with the therapy have an impact on changes in a tested organism. Hyperbaric oxygen has an influence on the effectiveness of medications. Research done by Yilmaz Korkmaz indicates increased effectiveness of angiotensin receptor blockers while using hyperbaric oxygen therapy to reduce proteinuria [7].

In 2014, American scientists measured kidney parameters in diabetic mice subjected to a pressure of 1.5 and 2.5 ATA four times a week. These animals were breathing pure oxygen in a hyperbaric chamber. The results of this experiment show improvement in the kidney parameters in mice treated with hyperbaric oxygen.

The authors of this experiment demonstrate that multiple exposures of tissue to the oxidative stresses induced in hyperbaric conditions, activate the antioxidant mechanisms in these tissues. It makes them more resistant to the chronic effect of cell stress and thus limits the destruction caused by a chronic disease, in this case diabetes [8].

It was proven that hyperbaric oxygen therapy leads to an inhibition of apoptosis in renal diabetic rats. Results of hyperbaric therapy were comparable to metformin treatment [9].

In literature we may find reports that hyperbaric therapy has protective effects on kidney tissues which have suffered from an acute ischemia - regardless of whether the treatment was carried out immediately after the ischemic event occurred or whether it was delayed $[10,11]$. The mechanism which leads to the cell protection is still not fully understood, but studies indicate that increased expression of antyapoptic protein Bcl-2 and the production of antioxidants such as superoxide dismutase plays a role in it [12].

Patients suffering from benign prostatic hypertrophy also experienced the positive effect of hyperbaric therapy. Scientists who performed experimental treatment in these patients indicate hypoxia of the detrusor muscle as a cause of urinary frequency. The treatment improved the ability of the bladder to hold more urine which resulted in reduction of the symptoms of pollakiuria, especially at night [13].

Results of a study conducted by Kalns I Pielmeier seem to be very promising. Researchers showed in their experiment that $1.5 \mathrm{~h}$ long exposure to oxygen under 6 ATA leads to synchronization of the prostate cancer cell cycle. A simultaneous increase in the number of cells retained during the sensitive stage of the cell cycle and the use of hyperbaric oxygen therapy could increase efficiency of chemotherapy and radiotherapy [14].

Patients with primary pyelonephritis, who underwent 10 cycles under 2.0-2.4 ATA of pressure for 60 minutes experienced a decrease of frequency of surgical procedures by $36.2 \%$. Postoperative hyperbaric therapy shortened hospitalization by $16.9 \%$. The increase in the glomerular filtration rate and renal hemodynamics improvement is caused by the positive outcome of therapy on inhibiting systemic inflammatory response [15].

Many reports of positive effects of hyperbaric therapy use in the treatment of hemorrhagic cystitis can be found in literature. Especially in inflammation that occurres after pelvic tumors radiotherapy. This noninvasive method of treatment proved successful also in patients for whom treatment with conventional methods had not brought improvement. It brought a resolution to symptoms such as hematuria and dysuria, with endoscopic images of bladder mucosum also improving [16].

Improved availability of oxygen to the damaged tissues and its positive effect on neoangiogenesis most likely contributed to the success of this therapy. Some publications also report the successful treatment of cystitis caused by acrolein-metabolite of cyclophosphamide [17].

There are known cases in which hyperbaric therapy successfully cured ischemic cystitis. Cystitis was observed in patients with chronic untreated urinary retention, and a patient suffering from gas cystitis [18,19].

Despite fears concerning this kind of treatment, the outlook for using oxygen therapy in treating diseases of the urinary tract seems to be a very promising. Another advantage of this method is its noninvasiveness and often good efficiency in cases where resistance to the recommended method of treatment can be noticed. Since many factors such as time, multiple applications, the parameters used and the medications taken by the patient affect the quality of the result, further studies are needed in order to refine and select a safe method of hyperbaric therapy for each patient. 


\section{BIBLIOGRAPHY}

1. Narożny W, Siebert J. Możliwości i ograniczenia stosowania tlenu hiperbarycznego w medycynie. Forum Med Rodz. 2007; 1(4):368-375. Polish [The possibilities and limitations of the use of hyperbaric oxygen in medicine];

2. Ganong WF.Fizjologia. Warszawa: PZWL; 1994;

3. Buda K, Daroszewska M, Ciesielska N, Sokołowski R,Ferenc S, Sysakiewicz M et al. Wytyczne Europejskiego Towarzystwa Medycyny Hiperbarycznej, Towarzystwa Medycyny Podwodnej i Hiperbarycznej i Narodowego Funduszu Zdrowia Rzeczpospolitej Polskiej na temat leczenia za pomoca hiperbarycznej terapii tlenowej na rok 2013. J Res Health Sci 2013; 3 (9):125-134 Polish[The guidelines of the European Society of Hyperbaric Medicine, the Society of Underwater and Hyperbaric Medicine and the National Health Fund Polish Republic on a hyperbaric oxygen therapy (HBOT) in 2013];

4. Gill AL, Bell CNA. Hyperbaric oxygen: its uses, mechanisms of action and outcomes. QJM. 2004;97: 385-395;

5. Hincu M, Petcu LC, Mehedinti R, Mehedinti T. Correlated histological and morphometric study of kidney and adrenal gland from Guinea pig exposed to hyperbaric-hyperoxic environment. Rom J Morphol Embryol 2006; 47(1):47-51;

6. Ay H, Uzum G, Onem Y, Aydinoz S, Yildiz S, Bilgi O, et al. Effect of Hyperbaric Oxygen on Cyclosporine-Induced Nephrotoxicity and Oxidative Stress in Rats. Ren Fail 2007; 29:495-501, DOI:10.1080/08860220701274983

7. Yilmaz MI, Korkmaz A, Kaya A, Sonmez A, Cagal K, Topal T, et al.Hyperbaric oxygen treatment augments the efficacy of a losartan regime in an experimental nephrotic syndrome model. Nephron Exp Nephrol. 2006;104(1):e15-22. DOI:10.1159/000093260;

8. Verma R, Chopra A, Giardina C, Sabissetti V, Smyth JA, Hightower LE, et al. Hyperbaric oxygen therapy (HBOT) suppresses biomarkers of cell stress and kidney injury in diabetic mice. Cell Stress Chaperones 2015; 20:495-505,DOI 10.1007/s12192-015-0574-3;

9. Nie WJ, Cao XQ, Shao GQ.Protective effects of hyperbaric oxygen treatment on kidney cells of type 2 diabetic rats. Sheng Li Xue Bao 2014 66(2): 186-194. DOI: 10.13294/j.aps.2014.0022;

10. Rubinstein I, Abassi Z, Milman F, Ovcharenko E, Coleman R, Winaver J,et al. Hyperbaric oxygen treatment improves GFR in rats with ischemia/reperfusion renal injury: a possible role for the antioxidant/oxidant balance in the ischemic kidney. Nephrol Dial Transplant. 2009; 24:428-436 DOI: 10.1093/ndt/gfn511;

11. Ilhan H, Eroglu M, Inal V, Eyi YE, Arziman I, Yildirim AO, et al. Hyperbaric Oxygen Therapy Alleviates Oxidative Stress and Tissue Injuryin Renal Ischemia/Reperfusion Injury in Rats. Ren Fail. 2012; 34(10): 1305-1308 DOI: 10.3109/0886022X.2012.723776;

12. Hink J, Jansen E. Are superoxide and/or hydrogen peroxide responsible for some of the beneficial effects of hyperbaric oxygen therapy? MedicalHypotheses 2001 57(6):764-769. DOI: 10.1054/mehy.2001.1488;

13. Loran OB, Vishnevskii EL, Vishnevskii AE. The role of detrusor hypoxia in the pathogenesis of urination disorders in patients with benign prostatic hyperplasia. Urol. Nefrol.(Mosk) 1996; 6:33-37;

14. Kalns JE, Piepmeier EH. Exposure to hyperbaric oxygen induces cell cycle perturbation in prostate cancer cells. In Vitro Cell Dev. Biol. Anim. 1999; 35(2):98-101.DOI: 10.1007/s11626-999-0008-6;

15. Sokolova Kha. The role of hyperbaric oxygenation in combined treatment of acute pyelonephritis. Urologiia. 2010; 5:10-4;

16. Weiss JP, Boland FP, Mori H, Gallagher M, Breretn H, Preate DL,et al. Treatment of radiation-inducted cystitis with hyperbaric oxygen. J. Urol.1985; 134(2):352-254;

17. Yazawa H., Nakada T, Sasagawa I,Miura M, Kubota Y. Hyperbaric oxygenation therapy for cyclophosphamide-inducted haemorrhagic cystitis Int Urol. Nephrol.1995;27(4): 381-385. DOI: 10.1007/BF02550072;

18. Lopez AE, Rodriguez S, Flores I: Management of ischemic hemorhhagic cystitis with hyperbaric oxygen therapy. Undersea Hyperb. Med 2001;28(1):35-36;

19. McCabe JB, Mc-Ginn Merrit W, Olsson D, Wright V, Camporesi EM. Emphysematous cystitis:rapid resolution of symptoms with hyperbaric treatment: a case report. Undersea Hyperb. Med. 2004; 31(3):281-284.

Małgorzata Skiba

Katedra i Zakład Histologii i Embriologii Uniwersytet Medyczny w Lublinie

UI. Radziwiłowska 1

20-080 Lublin 